无间隙原子钢高压扭转过程中塑性变形的滞后性 研究

\author{
宋月鹏 ${ }^{1,2}$, 张紫涵 ${ }^{1}$, 高东升 ${ }^{2 *}$, 陈苗苗 ${ }^{1}$, 李法德 ${ }^{1}$, Kim Hyoung-Seop ${ }^{3}$ \\ 1 山东农业大学机械与电子工程学院, 泰安 271018; \\ 2 山东农业大学园艺科学与工程学院, 泰安 271018; \\ 3 韩国浦项工科大学材料科学与工程学院, 浦项 790784, 韩国 \\ * E-mail: dsgao219@163.com
}

收稿日期: 2017-08-18; 接受日期: 2017-10-11; 网络出版日期: 2017-11-30

山东省现代农业产业技术体系果品产业创新团队资金(批准号：SDAIT-06-12)、国家十三五智能农机装备重点研发计划项目(批准 号：2016YFD0701701)、山东省农机装备研发创新计划项目(批准号：2017YF003)和山东农业大学“双一流”科技创新团队专项(批准号： SYL2017XTTD07)资助

摘要采用DEFORM-3D 有限元分析软件,对无间隙原子钢(IF钢)在高压扭转(HPT)中的扭转阶段大塑性变形 (SPD)过程进行模拟仿真, 通过分析试样的等效应变分布, 得到了 IF 钢在不同剖面的变形滞后性特征. 结果表明, 在扭转的前期阶段(不大于2周), IF钢试样表现出大塑性变形的滞后性: 试样边缘的等效应变值明显高于心部, 且沿径向由边缘到心部数值逐渐变小; 与试样的上表面相比, 下表面的等效应变明显较高,边缘大塑性变形区 域较大, 并且随着旋转角度、距心部距离的增加, 上表面大塑性变形的滞后性越来越明显.这说明在扭转的前 期阶段, 试样的中心部及上表面的塑性变形相对滞后, 并对其原因进行了初步分析, 这与其下模旋转及表面摩 擦密切相关, 理论分析、显微组织及硬度检测结果均验证了该模拟结果的可靠性.

关键词无间隙原子钢, 高压扭转, 大塑性变形滞后性, 有限元分析

\section{1 引言}

近年来, 块体超细晶(Ultrafine-Grained, UFG)材料 因具有优异的力学性能和加工性能, 如良好的塑性、 较高的强度以及可实现低温超塑性等, 备受材料科 学界关注. 制备块体超细晶材料的方法中, 大塑性 变形法(Severe Plastic Deformation, SPD) 最为常用 ${ }^{[1-4]}$. 大塑性变形技术通过大变形细化晶粒的原理可以使 材料的内部组织细化到亚微米乃至纳米级. 高压扭
转法(High-Pressure Torsion, HPT) 由于便于累积应变 和变形速度, 非常适合加工盘状材料和固化粉体材 料, 被认为大塑性变形法中细化晶粒最有效的工艺之 - ${ }^{[4,5]}$. 目前, 国内外学者利用高压扭转法, 成功制备了 $\mathrm{Al}, \mathrm{Mg}, \mathrm{Cu}, \mathrm{Si}, \mathrm{Ni}$, Ti等多种致密金属及其块体超细晶材 料 ${ }^{[6-14]}$.

高压扭转法分为压缩及扭转两个阶段, 宋月鹏等 人 $^{[5 \sim 7]}$ 采用计算机模拟仿真方法, 结合微观组织和性能 检测分析结果, 得出压缩阶段试样塑性变形不均匀的

引用格式: 宋月鹏, 张紫涵, 高东升, 等. 无间隙原子钢高压扭转过程中塑性变形的滞后性研究. 中国科学: 技术科学, 2018, 48: 154-160 Song Y P, Zhang Z H, Gao D S, et al. Deformation lagging characteristics of IF steel disks in the plastic deformation process of high pressure torsion (in Chinese). Sci Sin Tech, 2018, 48: 154-160, doi: 10.1360/N092017-00278 
特征规律, 而Iwaoka等人 ${ }^{[15 \sim 19]}$ 研究了高压扭转过程中, 压力、扭转速度、扭转圈数、摩擦系数对扭转工艺 影响的报道. 研究表明, 高压扭转过程中, 施加载荷、 摩擦系数、下模扭转速度等参数对高压扭转变形过 程的影响较大 ${ }^{[1,6,8,9]}$. 尤其是摩擦系数对试样不均匀塑 性变形特征影响最大 ${ }^{[6,7,18-20]}$, 但是需要指出的是, 到目 前为止, 对试样扭转阶段不同剖面所表现出的变形滞 后性特征国内外还没有报道.

本文利用有限元分析软件DEFORM-3D, 对高压 扭转试样塑性变形特征进行研究, 通过分析高压扭转 试样的等效应变分布规律, 结合理论分析、显微组织 观察与硬度测量结果, 研究IF钢试样在扭转初期阶段 不同剖面塑性变形的滞后性特征.

\section{2 有限元模型建立与试验设计}

高压扭转时, 试样被固定在下模的凹槽内, 上模通 过压力向下挤压试样, 使其产生轴向的压缩变形. 在 上下模具保持压力的同时, 下模转动, 通过主动摩擦 在其横截面上施加一个扭矩, 促使试样产生轴向压缩 和切向剪切变形. 其原理如图1所示.

模拟过程中, 选取DEFORM-3D材料库中自带的 $0.008 \% \mathrm{C}$ carbon steel (Machining) 材料作为 IF钢试样材 料的物性参数. 高压扭转的温度设置为常温, 此时不
需要对模具进行网格划分而看作刚性体, 这样可以大 大减少计算机资源及计算时间. 网格划分的结果关乎 计算结果的精度和计算规模的大小, 为保证模拟结果 的准确性并提高计算效率. 经过多方面均衡考虑, 对 试样的单元网格划分选择单元数为 22000 , 有限元模 型如图2(a)所示.

在坯料原始状态时, 为更好地观察试样等效应变 分布情况, 可以通过隐藏上下模具, 利用DEFORM后 处理中的Point Tracking选项, 在坏料沿半径的上下表 面, 分别选取 20 个均匀的点作为跟踪点, 点的选取方 式如图2(b)所示.

模拟的边界条件为: 压力 $2.5 \mathrm{GPa}$; 下模具旋转速 率 $1.0 \mathrm{rad} / \mathrm{s}$; 模具与试样之间的摩擦系数为 0.1 . 由于 下模具旋转速度较为缓慢, 大塑性变形过程中产生的 热量对应力应变的影响较小, 因此, 本文在模拟 IF钢 塑性变形时, 忽略了热量对变形过程的影响.

试验材料为韩国浦项制铁公司 (POSCO, Korea) 生产的 IF 热轧钢板, 成分 (wt $\%$ ) 为 $0.008 \% \mathrm{C}, 0.096 \% \mathrm{Mn}$, $0.045 \% \mathrm{Al}, 0.041 \% \mathrm{Ti}$, 其余为 $\mathrm{Fe}$. 对热轧板进行退火处 理 (为 $740^{\circ} \mathrm{C}$ 保温 $2 \mathrm{~h}$ 后炉冷)后加工成 $\varphi 20 \times 2 \mathrm{~mm}$ 试样, 初始晶粒尺寸为 $150 \sim 200 \mu \mathrm{m}$, 硬度为 $80 \mathrm{Hv}$. 按照模拟 边界条件进行高压扭转试验, 采用TH5型显微硬度计 测定试样的显微硬度, 用Caikon-4XCE型金相显微镜 进行组织观察并照相.
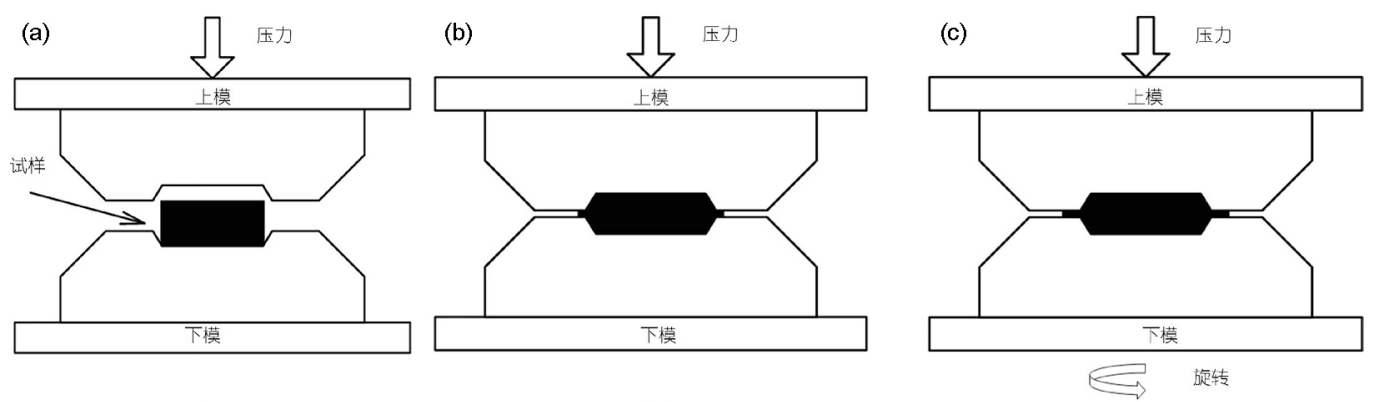

图 1 高压扭转原理图. (a) 试样放置; (b) 压缩阶段; (c) 扭转阶段
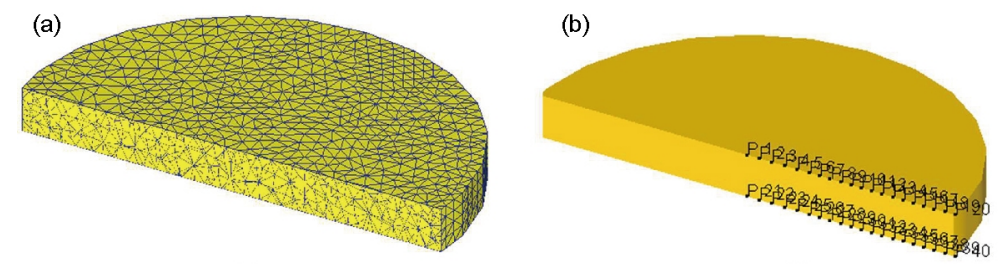

图 2 (网络版彩图)试样有限元模型及其上下表面跟踪点选取. (a) 试样有限元模型及其网格划分; (b) 沿半径方向跟踪点选取 


\section{3 结果与分析}

\section{1 扭转初期阶段IF 钢试样径向剖面变形滞后性}

图3为 $\mathrm{IF}$ 钢试样在 $2.5 \mathrm{GPa}$ 载荷下, 下表面在扭转 初期等效应变分布模拟云图, 其中(a) ( f) 反映了试样 旋转 $0,1 / 4,2 / 4,3 / 4,1$ 及 2 周时等效应变分布情况.

分析 IF 钢试样扭转不同角度后下表面的等效应 变云图, 可以看出, 随着扭转角度增加(图3(a) (f)), 试 样中心的等效应变变化非常小(等效应变值均为 1.0 左 右), 而边缘处大塑性变形区域将逐渐增加, 其变化特 征是, 扭转初期, 试样边缘处最大等效应变可达 10.69 , 如图3(b) 所示. 随着试样扭转角度的增加, 边缘处首 先产生大塑性变形, 然后逐渐向心部扩展, 因此, 在
高压扭转过程中, 试样各部位存在着不均匀变形特 征. 同时, 当扭转角度增加时, 试样飞边的面积逐渐增 大, 因此厚度将逐渐减小, 这已被众多研究结果所证 实 ${ }^{[13 \sim 19]}$.

进一步研究 IF钢试样在扭转 $1 / 4,1$ 及 2 周后, 上下 表面沿半径方向跟踪点等效应变分布规律, 其规律 如图4所示.

图4显示, IF钢试样扭转不同角度后, 上下表面沿 半径方向跟踪点等效应变分布规律基本相同, 即靠近 边缘处数值较大, 且随着扭转角度的增加而增加, 如 对于上表面, 扭转 $1 / 4,1$ 及 2 周后, 最边缘处的等效应变 分别为: $3.23,3.99$ 及 4.57 , 而对于下表面的等效应变则 为: $3.43,4.74$ 及 5.56 . (a)

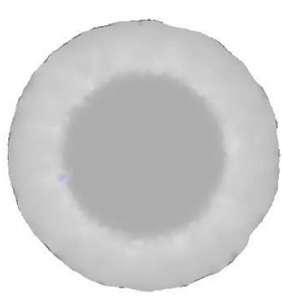

(d)

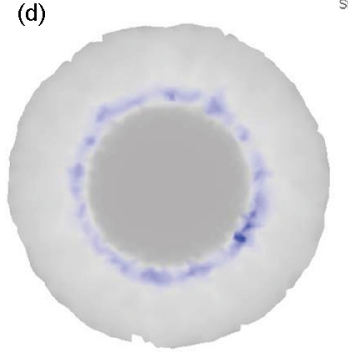

(b)
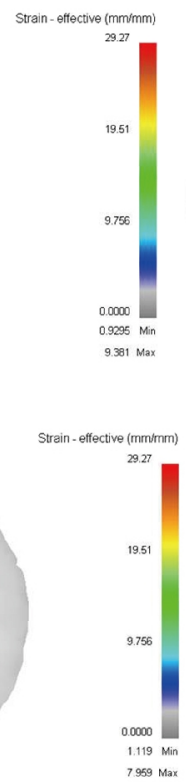

(e)
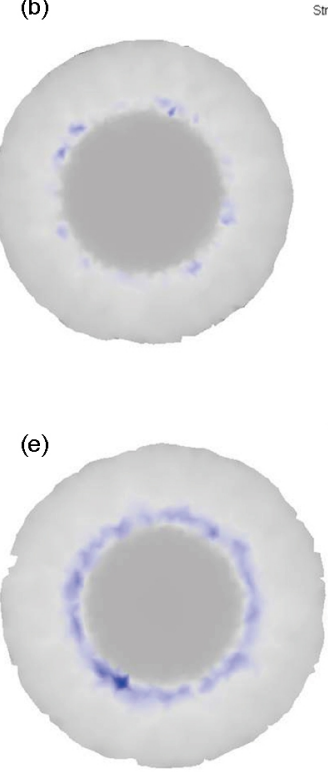

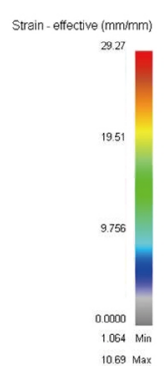

(c)
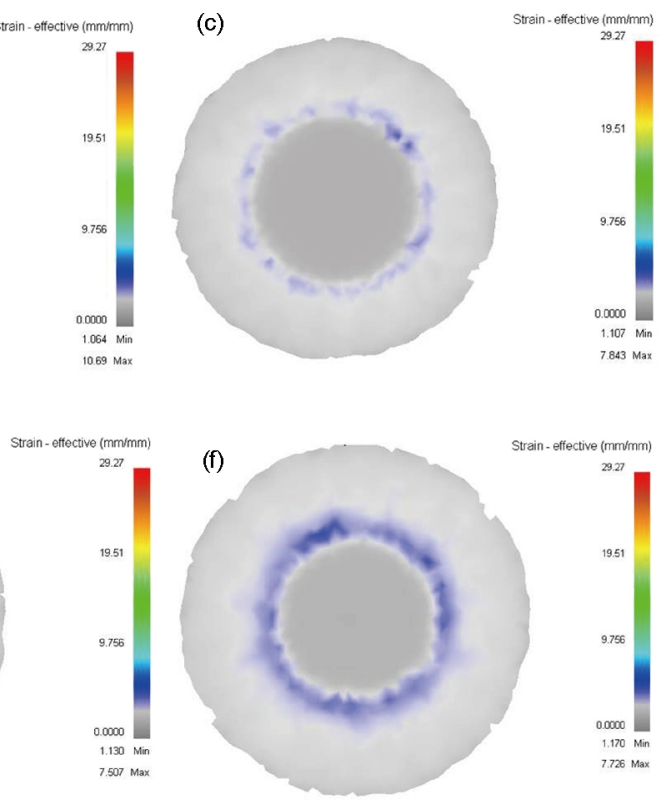

图 3 (网络版彩图)试样高压扭转变形的应变分布 (2.5 GPa). (a) 0 周; (b) 1/4周; (c) 2/4周; (d) 3/4周; (e) 1周; (f) 2 周
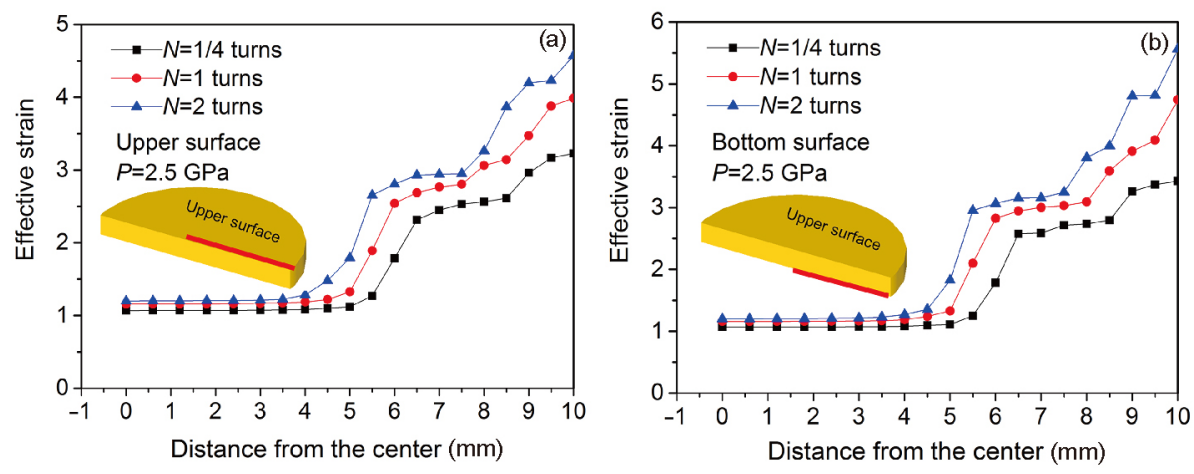

图 4 (网络版彩图)IF钢试样上下表面沿半径方向跟踪点等效应变分布规律. (a) 上表面; (b) 下表面 
文献 [21]给出的高压扭转不同部位等效应变 (Equivalent Von Mises strain)计算公式:

$\varepsilon_{\mathrm{eq}}=\frac{2 \pi N r}{h \sqrt{3}}$,

式中, $N$ 为扭转角度 $(\mathrm{rad}), r, h$ 分别为距心部距离 $(\mathrm{mm})$ 和试样的厚度 $(\mathrm{mm})$.

前面的研究结果表明(图3), 随着扭转角度 $N$ 逐渐 增加, 试样厚度 $h$ 将逐渐减小, 由公式(1)可以明显看 出, 等效应变 $\varepsilon_{\mathrm{eq}}$ 与 $r$ 并非线性增加关系, 图 4中上下表 面大变形区域的等效应变分布曲线证明了这一点. 同 时, 当 $r$ 达到一定数值时, 也就是扭转过程中等效切变 应力 $\sigma_{\mathrm{eq}}$ 大于该点材料的切变强度时, 则该区域将发生 大塑性变形. 公式(1)还显示, 随着扭转角度 $N$ 逐渐增 加, $r$ 数值将逐渐减小, 即大塑性变形区域将从边缘逐 渐向心部扩展.

当试样某处开始发生大塑性变形时, 其等效应变 值将急速变化, 相应的曲线斜率将急剧增加, 进一步 研究下表面扭转不同角度时, 沿径向跟踪点等效应 变值斜率变化情况(如图4(b)), 可以看出, 当试样扭转 $1 / 4$ 周时, 等效应变分布曲线在 $r=5 \mathrm{~mm}$ 处斜率急剧增
加, 由此说明此处开始发生大塑性变形, 因此试样的 大塑性变形区域为 $r=5 \sim 10 \mathrm{~mm}$. 相同情况, 当扭转 1 周 时, 该区域变为 $r=4.5 \sim 10 \mathrm{~mm}$ 处, 而扭转 2 周时又扩大 到 $r=4 \sim 10 \mathrm{~mm}$ 处, 因此, 结合图3模拟结果, 可以看出, 随着扭转角度增加, 大塑性变形区域将从边缘逐渐向 心部扩展.

这从理论上验证了上述模拟结果的可靠性.

\section{2 扭转初期阶段IF钢试样轴向剖面的变形滞后 性}

图 5 为 IF钢试样在 $2.5 \mathrm{GPa}$ 压力下, 扭转不同角度 $(1 / 4,2 / 4,1,2$ 周)后, 轴向剖面上下表面沿半径方向的 等效应变分布曲线. 图中显示, 试样扭转一定角度时, 上下表面的等效应变值在心部 $(r$ 值在一定范围内)变 化较小, 且变化规律基本相同, 而试样的边缘区域等 效应变值较大, 大塑性变形首先发生在试样边缘.

随着 $r$ 值逐渐增加, 下表面的等效应变值总是高于 上表面的数值. 如图 5 (a)显示, 当试样扭转 $1 / 4$ 转时, 在 $r=0 \sim 5 \mathrm{~mm}$ 的区域内, 下表面的等效应变基本与上表面 相同(约为 1.0 ), 而在 $r=6.5 \mathrm{~mm}$ 处, 上、下表面的等效应
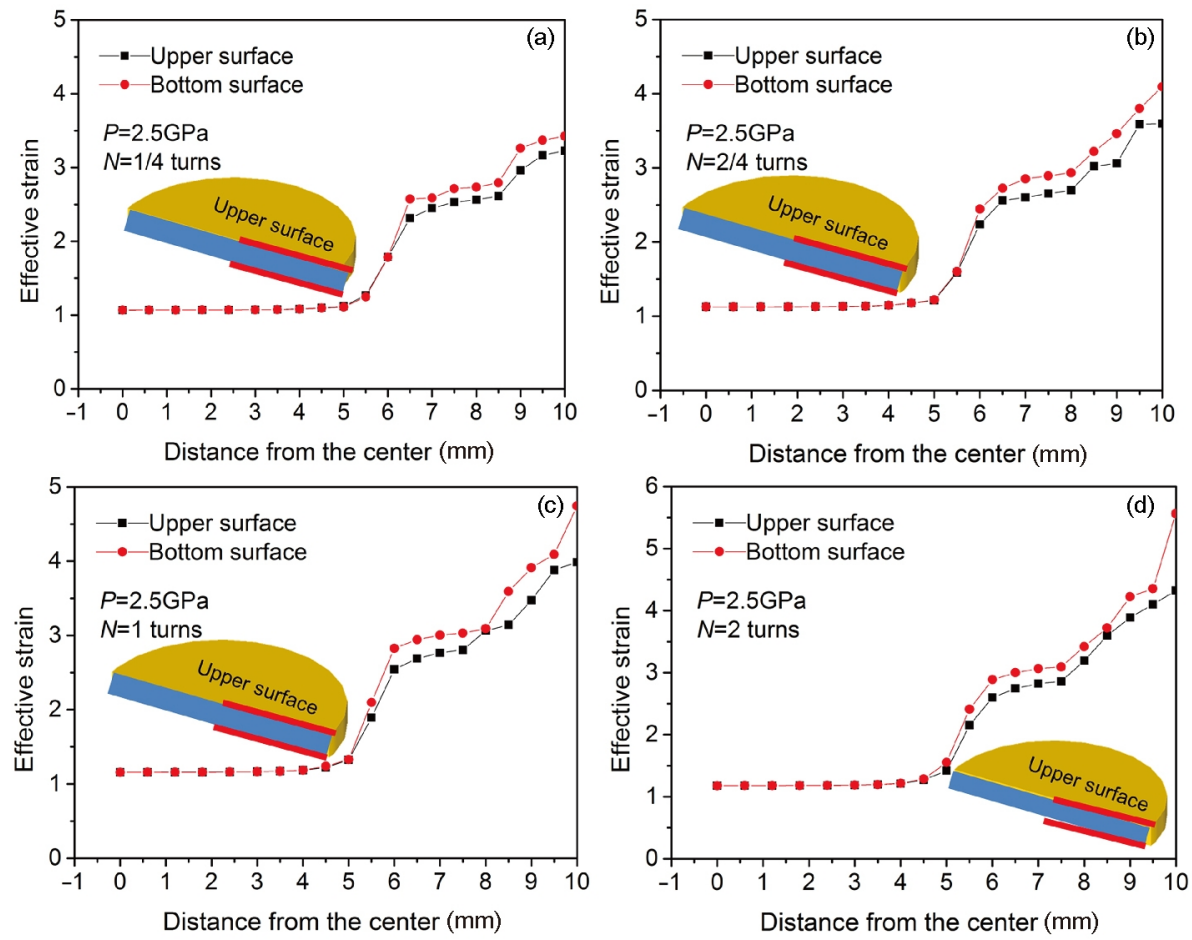

图 5 (网络版彩图)试样剖面上下表面等效应变沿径向的分布. (a) 1/4周; (b) 2/4周; (c) 1周; (d) 2 周 
变值开始出现差别, 数值分别为 2.3 和 2.5. 试样边缘处, 这种差别最大, 如在 $r=10 \mathrm{~mm}$ 处(即试样的最边缘处), 扭转不同角度后( $1 / 4,2 / 4,1$ 及 2 周), 上表面的等效应变 值依次为 $3.2,3.5,3.9,4.5$, 而下表面的等效应变值分别 为 $3.4,4.0,4.7,5.6$.

同时还应注意到, 当试样旋转一定角度时, 随着 距离中心距离 $(r)$ 的增加, 上下表面的等效应变值的 变化速率均产生较大增加, 如图 5(c) 所示, 在 $r=5 \mathrm{~mm}$ 处, 上、下表面的等效应变斜率分别为 $0.67,0.86$, 而 在 $r=5.5 \mathrm{~mm}$ 处, 斜率分别为 $1.21,1.49$. 由此可以看出, 下表面的等效应变值先于上表面增加, 且下表面的等 效应增加较快. 在试样的边缘处, 上表面的滞后性最 为明显, 此时下表面的等效应变值为 4.74 , 远大于上表 面的 3.98 .

等效应变值反映了塑性变形的程度, 因此, 这种 差别实际反映的是不同表面在扭转初期产生塑变的 滞后性特征, 这种滞后性产生的原因可能是, 试样的 扭转过程是由下模带动的, 下表面将先于上表面发生 塑性变形而形成一定的变形滞后性, 这将导致整个轴 向剖面塑性变形的不均匀性 ${ }^{[6,18,20]}$. 随着旋转角度与 $r$ 值增加, 上表面的变形滞后性越来越明显.

由此可以看出, 模具与试样的摩擦对塑变滞后性 具有重要作用, 陈苗苗 ${ }^{[20]}$ 的研究结果表明, 当摩擦系 数逐渐增大时, 这种滞后性将越来越显著.

\section{3 扭转初期阶段IF钢试样变形滞后性的微观组 织及其硬度分布}

一般情况下, 晶粒尺寸是影响材料硬度的重要因
素, 晶粒越细小硬度越大, 因此, 晶粒尺寸及硬度分布 可以反映出材料塑性变形应变数值的大小.

图6(a)为IF钢试样在 $2.5 \mathrm{GPa}$ 作用下, 旋转 $2 / 4$ 转时 边缘处的显微组织, 图6(b)为上下表面沿半径方向测 得的硬度值分布.

由于大塑性变形导致晶粒细化, 试样下表面边缘 部位晶粒细化区域明显大于上表面, 即下表面的大塑 性变形区(SPD)较大, 边缘处的两排硬度压痕大小显示 出上下表面硬度值的差异(如图6(a)所示). 图6(b)为沿 半径方向上下表面硬度值的分布规律，当 $r<5 \mathrm{~mm}$ 时， 上下表面硬度值相差不大, 但当 $r=5 \mathrm{~mm}$ 时, 上表面硬 度明显低于下表面硬度值, 这和前面得到的结论极为 吻合. 与心部相比, 试样边缘的等效应变值最大, 中心 最小, 因此试样边缘的晶粒细化, 硬度高. 此外, 模拟 结果显示(如图5(b)所示), 试样的下表面等效应变高于 上表面, 其硬度值也显示出此规律.

为进一步研究试样滞后性的规律, 测得试样扭 转 1 周时距离上表面不同位置处的硬度值, 如表 1 所 示. 由表 1 中的硬度值可看出, 在距离试样上表面 1 和 $0.5 \mathrm{~mm}$ 处, 试样的硬度值呈现随半径增加而逐渐增加 的趋势. 这验证了文中提出的试样沿径向滞后性的规 律, 即试样的心部的塑性变形滞后于试样边缘出的塑 性变形. 当 $r>7 \mathrm{~mm}$ 时, 距离上表面 $0,0.5,1 \mathrm{~mm}$ 位置处 的硬度值可以明显看出, 在距试样中心相同位置处, 随 着到上表面距离的增加, 试样的硬度值逐渐增加, 试 样内部也会出现上表面滞后于下表面的规律. 由此说 明, 在高压扭转初期, IF钢大塑性变形均存在非常显 著的滞后性现象.
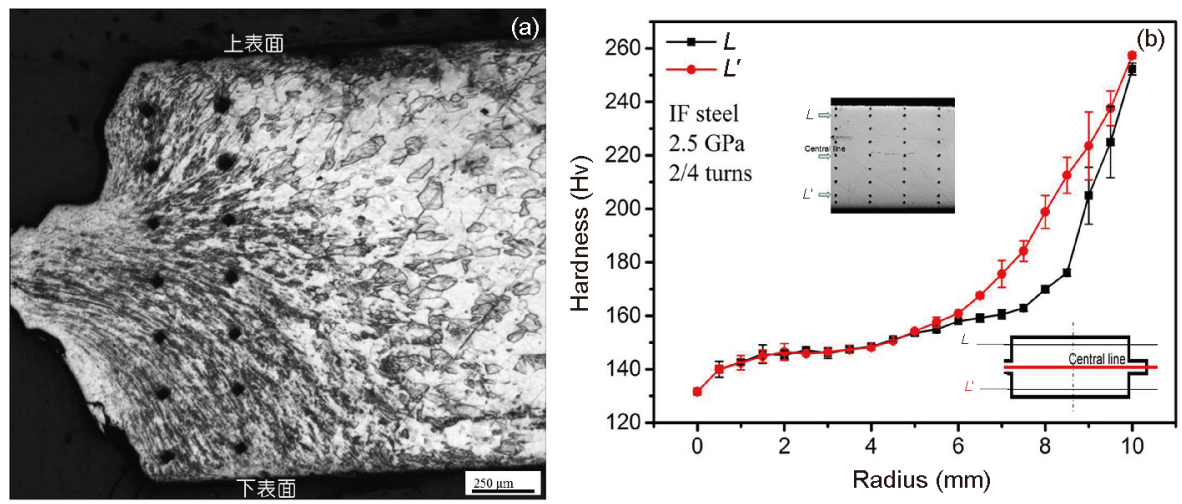

图 6 (网络版彩图)IF钢旋转 $2 / 4$ 周时边缘显微组织及其硬度分布. (a) 显微组织; (b) 上下表面硬度分布 
表 1 试样扭转1周时距离上表面不同位置处的硬度值(单位: Hv)

\begin{tabular}{cccccccccccc}
\hline 距离上表面 & \multicolumn{10}{c}{ 距离试样中心的距离 $r(\mathrm{~mm})$} \\
\cline { 2 - 12 } 的距离 $(\mathrm{mm})$ & 0 & 1 & 2 & 3 & 4 & 5 & 6 & 7 & 8 & 9 & 10 \\
\hline 0 & 134.9 & 144.4 & 148.8 & 160.4 & 170 & 193.8 & 242.7 & 258.8 & 278.0 & 288.2 & 303.5 \\
0.5 & 142.4 & 143.0 & 147.7 & 147.4 & 156.8 & 186.2 & 230.5 & 258.4 & 288.2 & 331.7 & 331.35 \\
1 & 153.8 & 142.1 & 148.9 & 146.7 & 154.4 & 189.4 & 218.6 & 262.4 & 289.0 & 328.1 & 359.0 \\
\hline
\end{tabular}

\section{4 结论}

(1) 在高压扭转的初期扭转阶段(不大于 2 周), IF 钢试样心部的等效应变值均低于边缘处, 且变化较小 ( $r$ 值在一定范围内). 随着扭转角度的增加, 试样的边 缘处等效应变值增大, 发生大塑性变形并逐渐向心部 扩展, 即试样心部的塑性变形滞后于边缘;
(2) 高压扭转初期阶段, IF钢试样上下表面的等效 应变值变化规律基本相同, 但当 $r$ 值超过一定范围时, 下表面的等效应变值将高于上表面, 反映出上表面大 塑性变形的滞后性特征, 并且随着扭转角度、 $r$ 值及 摩擦系数的增加, 这种滞后性将越来越明显;

(3) 理论分析、试样显微组织观察及硬度分布测 量结果均证明了变形滞后性模拟结果的可靠性.

\section{参考文献}

1 Um H Y, Park B H, Ahn D H, et al. Mechanical and biological behavior of ultrafine-grained Ti alloy aneurysm clip processed using high-pressure torsion. J Mech Behav BioMed Mater, 2017, 68: 203-209

2 Li J, Xu J, Guo B, et al. Shear fracture mechanism in micro-tension of an ultrafine-grained pure copper using synchrotron radiation X-ray tomography. Scripta Mater, 2017, 132: 25-29

3 Faraji G, Kim H S. Review of principles and methods of severe plastic deformation for producing ultrafine-grained tubes. Mater Sci Tech, 2017, 33: $905-923$

4 Park B H, Um H Y, Kim J G, et al. Large deformation behavior of twin-induced plasticity steels under high-pressure torsion. Met Mater Int, 2016, 22: 1003-1008

5 宋月鹏, 陈苗苗, 高东升, 等. 高压扭转法制备超细晶材料的研究进展. 热加工工艺, 2017, 3: 6-9

6 Song Y P, Chen M M, Xu B Y, et al. Effects of friction and anvil design on plastic deformation during the compression stage of high-pressure torsion. Korean J Metals Mater, 2016, 54: 831-837

7 Song Y, Wang W, Lee D J, et al. Thickness inhomogeneity in hardness and microstructure of copper after the compressive stage in high-pressure torsion. Met Mater Int, 2015, 21: 7-13

$8 \mathrm{Xu}$ J, Wang X, Shirooyeh M, et al. Microhardness, microstructure and tensile behavior of an AZ31 magnesium alloy processed by high-pressure torsion. J Mater Sci, 2015, 50: 7424-7436

9 Roh A, Um H Y, Kim D, et al. Influence of high-pressure torsion and hot rolling on the microstructure and mechanical properties of aluminumfullerene composites. J Mater Sci, 2017, 52: 11988-12000

10 Abd El Aal M I. Effect of high-pressure torsion processing on the microstructure evolution and mechanical properties of consolidated micro size $\mathrm{Cu}$ and $\mathrm{Cu}-\mathrm{SiC}$ powders. Adv Powder Tech, 2017, 28: 2135-2150

$11 \mathrm{Xu} \mathrm{J}$, Li J, Wang C T, et al. Evidence for an early softening behavior in pure copper processed by high-pressure torsion. J Mater Sci, 2016, 51: 1923-1930

12 Edalati K, Shao H, Emami H, et al. Activation of titanium-vanadium alloy for hydrogen storage by introduction of nanograins and edge dislocations using high-pressure torsion. Int J Hydrogen Energ, 2016, 41: 8917-8924

13 Maier G G, Astafurova E G, Melnikov E V, et al. Evolution of grain-subgrain structure and carbide subsystem upon annealing of a low-carbon low-alloy steel subjected to high-pressure torsion. Phys Met Metallogr, 2016, 117: 1101-1110

14 An X H, Lin Q Y, Sha G, et al. Microstructural evolution and phase transformation in twinning-induced plasticity steel induced by high-pressure torsion. Acta Mater, 2016, 109: 300-313

15 Iwaoka H, Horita Z. High-pressure torsion of thick Cu and Al-Mg-Sc ring samples. J Mater Sci, 2015, 50: 4888-4897 
Shahmir H, Langdon T G. Characteristics of the allotropic phase transformation in titanium processed by high-pressure torsion using different rotation speeds. Mater Sci Eng-A, 2016, 667: 293-299

17 Alizadeh R, Mahmudi R, Ngan A H W, et al. Superplasticity of a nano-grained Mg-Gd-Y-Zr alloy processed by high-pressure torsion. Mater Sci Eng-A, 2016, 651: 786-794

18 Song Y, Chen M, Xu B, et al. Effect of revolution on inhomogeneous deformation of IF steel in high pressure torsion. MSA, 2016, 07: 673-679

19 宋月鹏, 陈苗苗, 徐保岩, 等. 高压扭转IF钢压缩阶段的不均匀变形. 材料热处理学报, 2017, 38: 105-110

20 陈苗苗. 高压扭转试样不均匀塑变过程仿真及其实验验证. 硕士学位论文. 泰安: 山东农业大学, 2017. 32-36

21 Zhilyaev A, Langdon T. Using high-pressure torsion for metal processing: Fundamentals and applications. Prog Mater Sci, 2008, 53: 893-979

\title{
Deformation lagging characteristics of IF steel disks in the plastic deformation process of high pressure torsion
}

\author{
SONG YuePeng ${ }^{1,2}$, ZHANG ZiHan ${ }^{1}$, GAO DongSheng ${ }^{2}$, CHEN MiaoMiao', \\ LI FaDe ${ }^{1} \&$ KIM Hyoung-Seop ${ }^{3}$ \\ ${ }^{1}$ Mechanical and Electronic Engineering College,Shandong Agricultural University, Tai'an 271018, China; \\ ${ }^{2}$ Horticulture Science and Engineering College, Shandong Agricultural University, Tai'an 271018, China; \\ ${ }^{3}$ Department of Materials Science and Engineering, Pohang University of Science and Technology, Pohang 790784, Korea
}

Deformation lagging characteristics of IF steel disks in the early torsion stage in the process of High-Pressure Torsion (HPT) are investigated with DEFORM-3D finite analysis software through the effective strain distribution of HPT sample by computer simulation and experimental verification. The results indicate that in the early torsion stage (not more than 2 turns), deformation lagging characteristics will exhibit remarkably in the severe plastic deformation (SPD) process. As to the Equivalent Von Mises strain, values in the sample edge is significantly higher than that in center, gradually decreasing from the edge to the center along the radius direction. Compared with the upper surface of sample, the effective strain of the bottom surface is obviously increasing. The SPD area in upper surface of sample is smaller than bottom surface of sample. Following the increasing rotation angel and the distance from the center, the deformation lagging characteristics of upper surface will appear more obviously. The mechanism of characteristics analysis indicate that the active rotation for the bottom die and friction plays an important role in the deformation lagging process. The theoretical analysis, the micro-structure and hardness investigation all agree well with the simulation results.

interstitial free steel, high-pressure torsion, severe plastic deformation lagging, finite element analysis

doi: $10.1360 / \mathrm{N} 092017-00278$ 